\title{
The Evolution of Economic Activity in the Rural Area of Region 2 South - East
}

\author{
Daniela - Lavinia Balasan ${ }^{1,1}$, Dragoș Horia Buhociu ${ }^{2}$ \\ ${ }^{1}$ University "Lower Danube" of Galați, Doctoral School of Fundamental Sciences and Engineering, \\ 800201, Galați, Romania \\ ${ }^{2}$ University Architecture and Urbanism "Ion Mincu" Bucharest, Arh. Chief City Hall Galați, Romania
}

\begin{abstract}
When we talk about economic development, we can refer to improve the standard of living and the prosperity of the population. This is due by increasing per capita income. In order to analyze economic activity, severe indicators must be studied, namely productivity, economic growth rate, labour force share, gross domestic product.

In order to carry out as accurate an analysis as possible, it is required to discover the bottlenecks and problems that Region 2 South East makes and to develop a set of reservations and indications leading to the reduction and, why not, the removal of negative aspects.

The main purpose of this work is to achieve a strategic plan by studying the current state and the impact of the economic system in recent times in all its forms, with a view to the development of the countryside of Region 2 South - East.

I set out to create a website based on the advice of small rural entrepreneurs that evolves gathering information in realistically identifying all the strengths and concentrating them in the region's potential innovation.
\end{abstract}

Keywords: labour force, rural development, entrepreneurs, population.

\section{Introduction}

Rural development involves diversifying activities and contributing to initiatives that boost rural living standards. This development is based on the labour market, attracting investment in the countryside, developing infrastructure, improving the field such as education and health.

Iset out to analyse the business environment in the region concerned, as it plays a key role in the process of economic growth.

Sustainable and sustainable development is based on the following aspects, namely:

$>$ Economic development in the rural area leading to a decrease in poverty levels and the development of living standards;

$>$ Combating climate change and careful management of natural resources in the analyzed environment;

$>$ Creating and maintaining jobs through the development of businesses, the labour market;

*Corresponding author: lavinia.balasan@,ugal.ro 
Developing the quality of the environment that surrounds us;

This work is based on a careful analysis of the qualitative and quantitative information leading to the detailed study of Region 2 South -East with a view to establishing a conclusive set of proposals to help the sustainable and sustainable development of the Region.

The work is based on the outline of two major chapters, namely the territorial profile of the region with the set of characteristic elements and the evolution of the level of economy and the impact of the need for skilled labour.

\section{Territorial profile of Region 2 South - East}

The rural environment consists of all activities taking place outside the urban area and involves three essential elements, namely (Bold I.Baig E., Drăghici N., Rural area definition, organisation, development, Timişoara, Mirton Publishing House, 2003, p. 1521):

$>$ Administrative communities consisting of relatively few members and having mutual relations;

$>$ Increased dispensation of population and collective services;

$>$ The special economic role of agriculture and forestry.

In the provisions of Law No. 315 of 2004 are set out the objectives, institutional framework, competences and instruments specific to regional development policy in our country. According to this law, 8 development regions are established in Romania, as can be seen in the figure below (Evolution of economic development in the South-East Region, Project co-financed from the ERDF through POR 2014-2020, accessed on 21.10.2020).

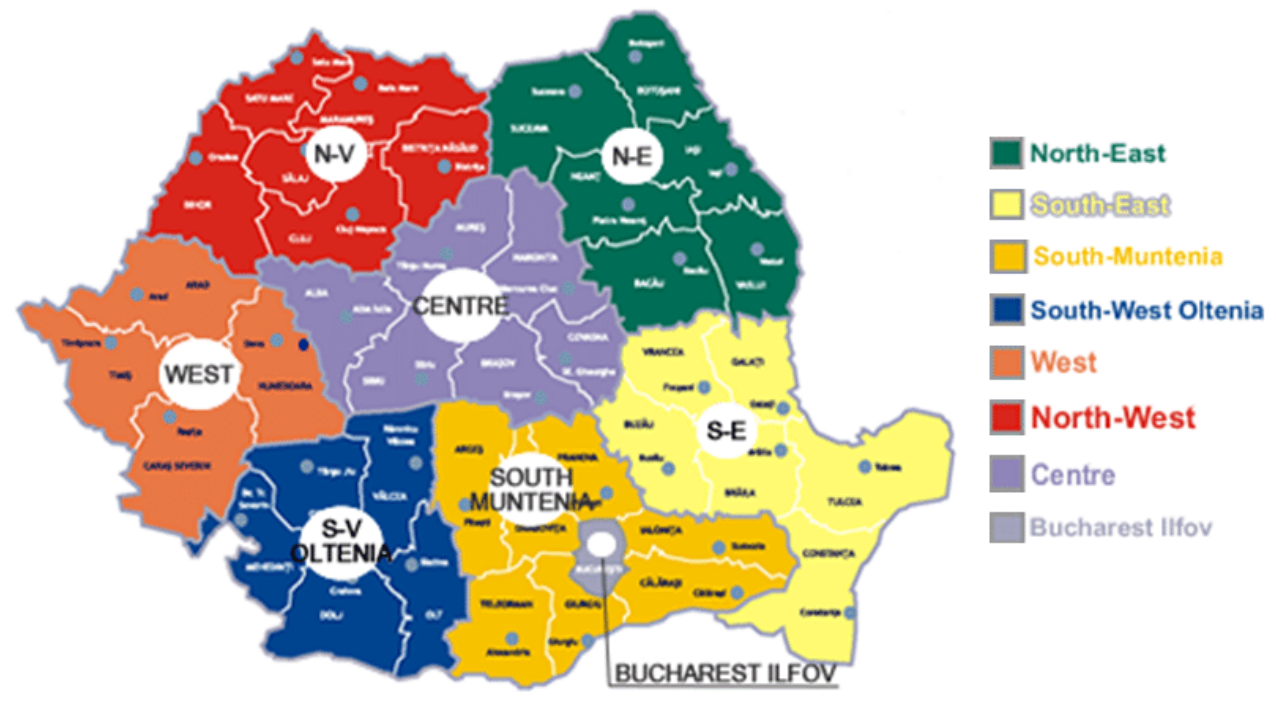

Figure No. 1. Romania's development regions

Source: Image taken from https://www.researchgate.net/figure/Development-regions-ofRomania_fig2_228267981 website

Romania is a country where rural life prevails, but agriculture is a key role in the rural economy, especially in the achievement of jobs.

The definition of rural development is inscribed in a broader concept, that of the rural economy, as a branch of economic science that intersects with rural areas and agriculture, with the economy of the environment and the economy of development. At the heart of the 
rural economy is the farm economy with its valences given by markets, agri-alementary industries, which make the analyses circumscribed to the rural economy related to rural policy, agri-food consumption and agricultural policy (Boussand J. M., Introduction a l'Economy Rural, Publishing GILLAS Paris, 1992).

Region 2 South - East is located in the South-East part of Romania and borders the North-East Region, the Centre Region, the South Region - Muntenia and the BucharestIlfov Region. The region is the eastern border point of the European Union, and in the East it can enjoy the fact that it borders the Black Sea, this giving it the chance to develop the maruitim and river-maritime transport, thus attracting foreign investors. The region groups 6 counties, 35 cities and 339 communes, as can be seen below.

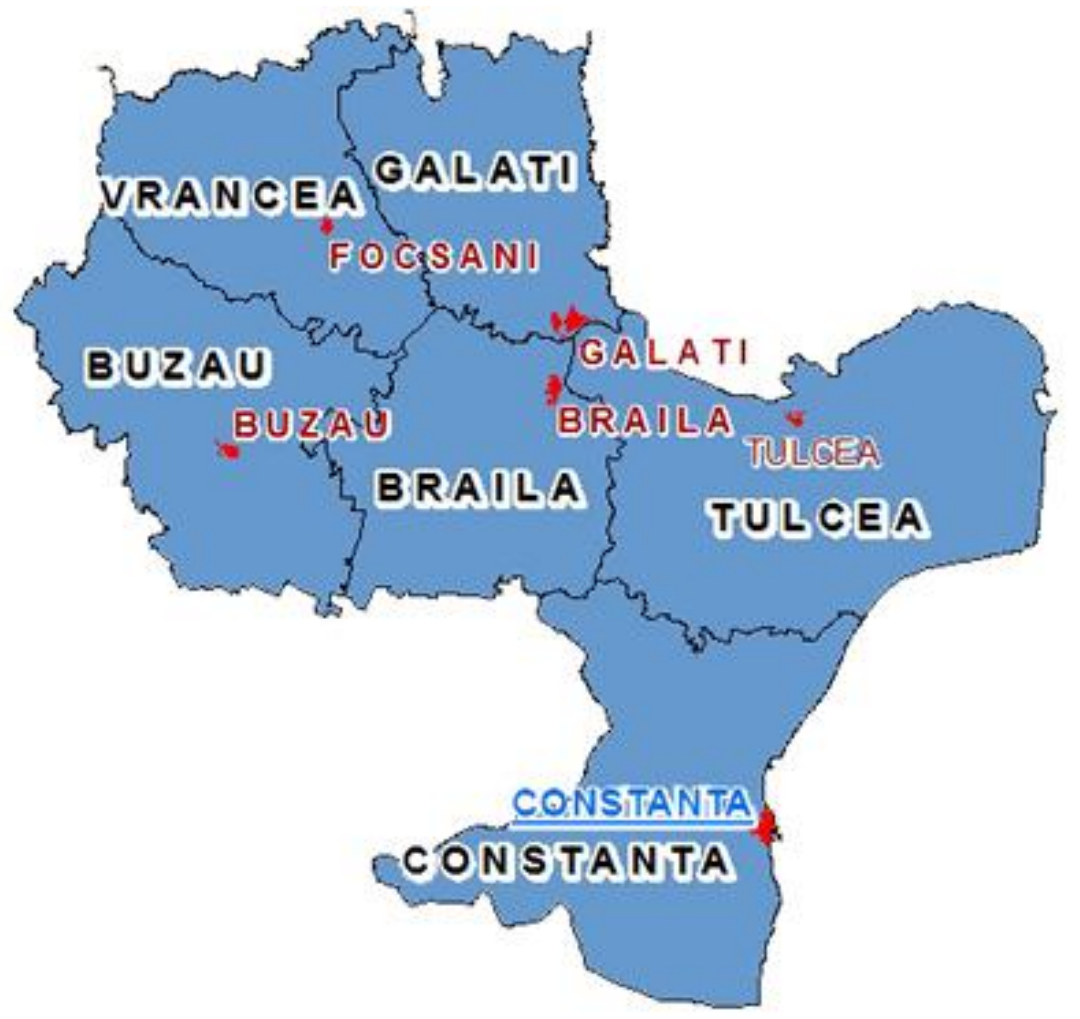

Figure No. 2. Counties of the Region 2 South - East

Source: Image taken from the website

http://static.anaf.ro/static/10/Galati/prezentare_regiune_gl_2014-07-11.htm accessed on 21.10.2020

Romania has increased development potential, but is not used to the maximum. It ranks 7 th in the European Union by area and number of inhabitants, and geographical areas are balanced.

An important feature of the region is high tourism due to the Black Sea coast and the Danube Delta, but also due to the spa-climatic resorts, the monasteries of Dobrogea and the mountains of the Vrancei area.

The South-East region ranks first in the Romanian vineyard ranking, with vineyards producing both national and international wines.

Region 2 South - East represents $15 \%$ of the area of our country. Here, the most bitter area is owned by Tulcea County, and at the opposite pole, Galați has the smallest area. 


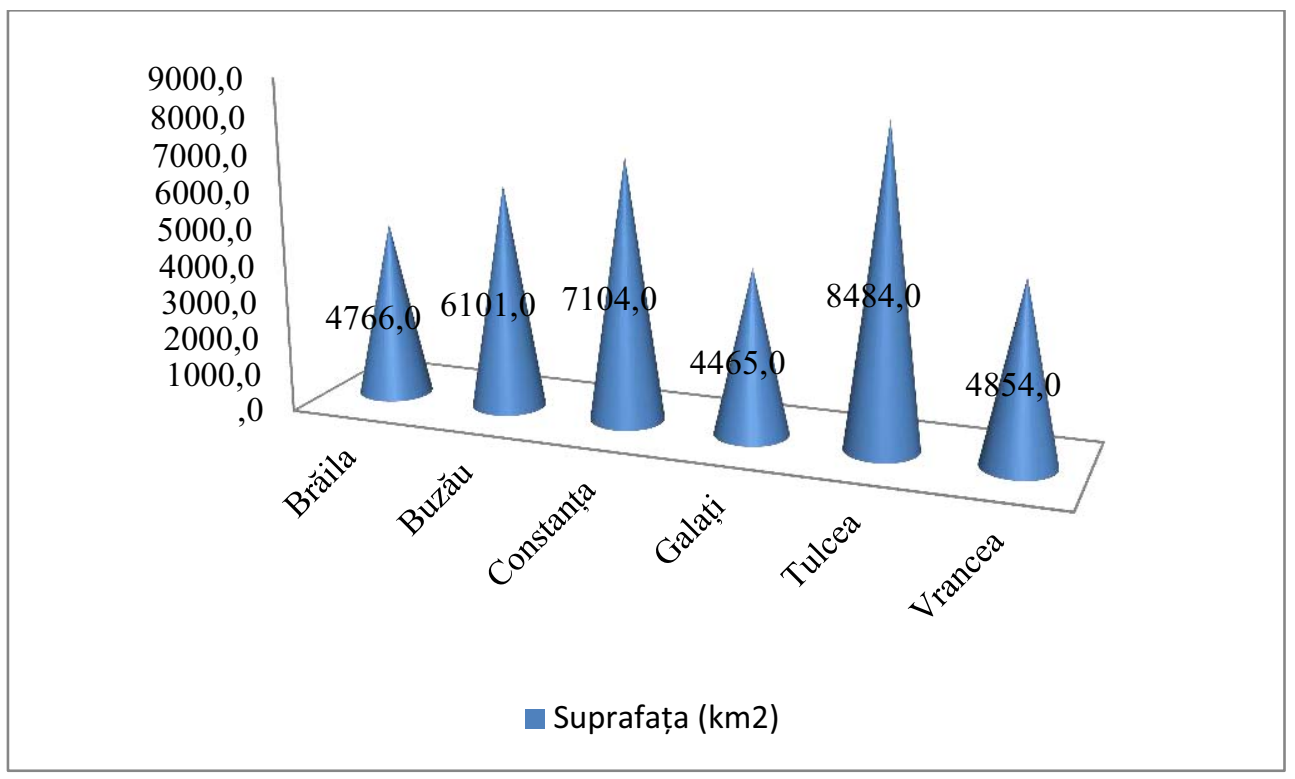

Figure No. 3. Counties of the South-East Region by area

Source: Own processed data from INS, TEMPO - Online, 2019

In recent years, there have been population declines in both urban and rural areas. Rural areas have an increased gap with urban areas and are defined by: persistent structural deficiencies (increased number of the population employed in agriculture, ageing population, a large number of subsistence holdings), low value added of agri-food products, lower yields and labour productivity in subsistence agriculture, weak entrepreneurial spirit in the development of economic activities, low access to credit, a non-functioning land market, modest export orientation, investment in insufficient relative research and development, poorly developed services and infrastructure, a large number of inhabitants at risk of poverty (http://www.madr.ro/docs/dezvoltare-rurala/programare-20142020/strategia-de-dezvoltare-rurala-2014-2020-versiunea-I-nov2013-update.pdf Accessed 30.03.2020).

About half of the region's population is in the countryside. Constanta and Galați have a predominantly urban population, and at the opposite turn of Buzau, Tulcea and Vrancea are characterized by a predominantly rural population. Constanta is the county with the highest share of the population in the urban area.

\section{Progress of economic development in Region 2 South East}

If we refer to the average number of employees, the region is experiencing decreases, and if in the past there were major differences between the number of male employees and the number of female employed, these figures are now almost equal.

In the figure below we see the counties of the Upper-East region according to the population. 


\section{Population \%}

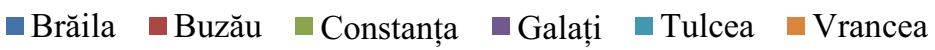

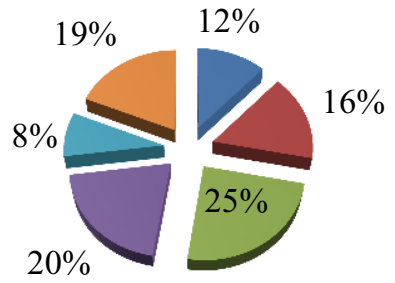

Figure No. 4. Counties of Region 2 South - East by number of inhabitants

Source: Own processed data from the Statistical Yearbook of Romania, INS, Bucharest

If we refer to the employment rate by residenceenvironment, we can see that young people up to 24 years of age and the age group between 55 and 64 are more prevalent in urban areas, while middle groups prefer rural areas.

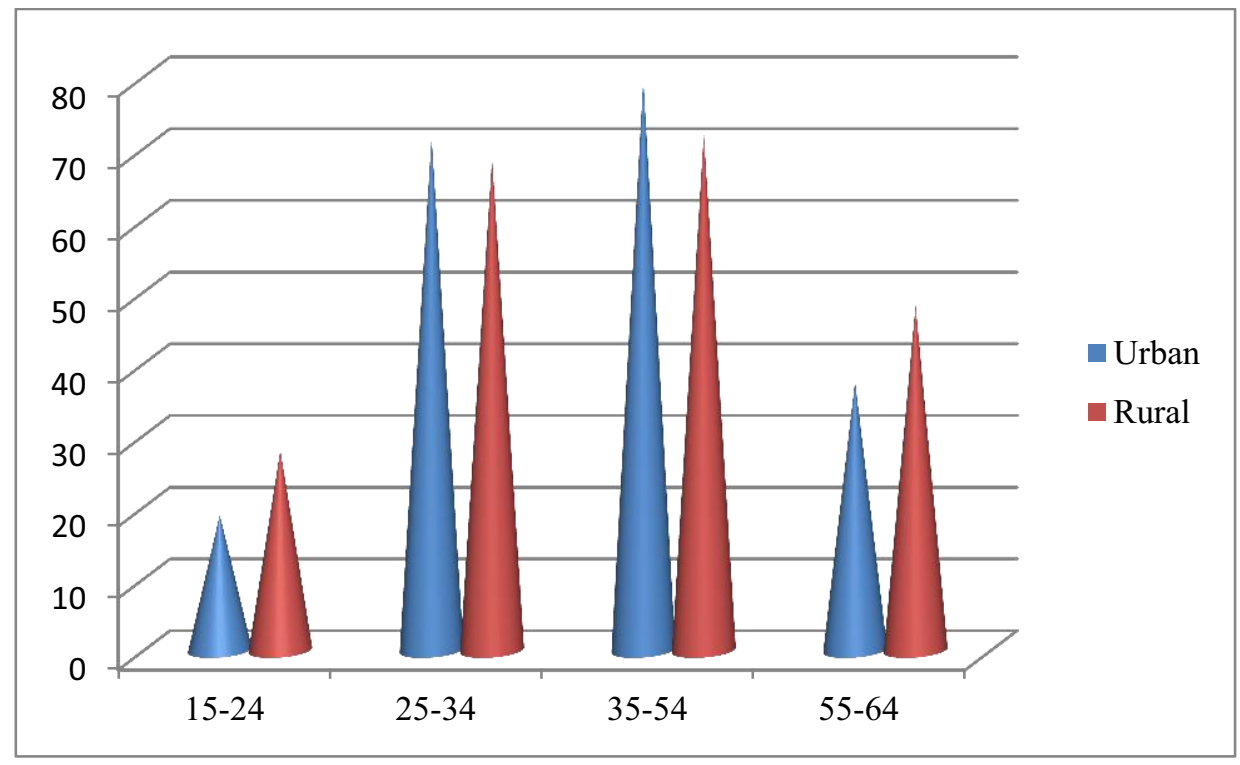

Figure No. 5. Occupancy by residence averages and age groups (2018)

Source: Own processed data from INS, TEMPO - Online, 2020

If we look at the two neighbouring towns on the Danube, namely Brăila and Galați, we will see a sharp decline in the rural population of Brăila. 


\section{Population}

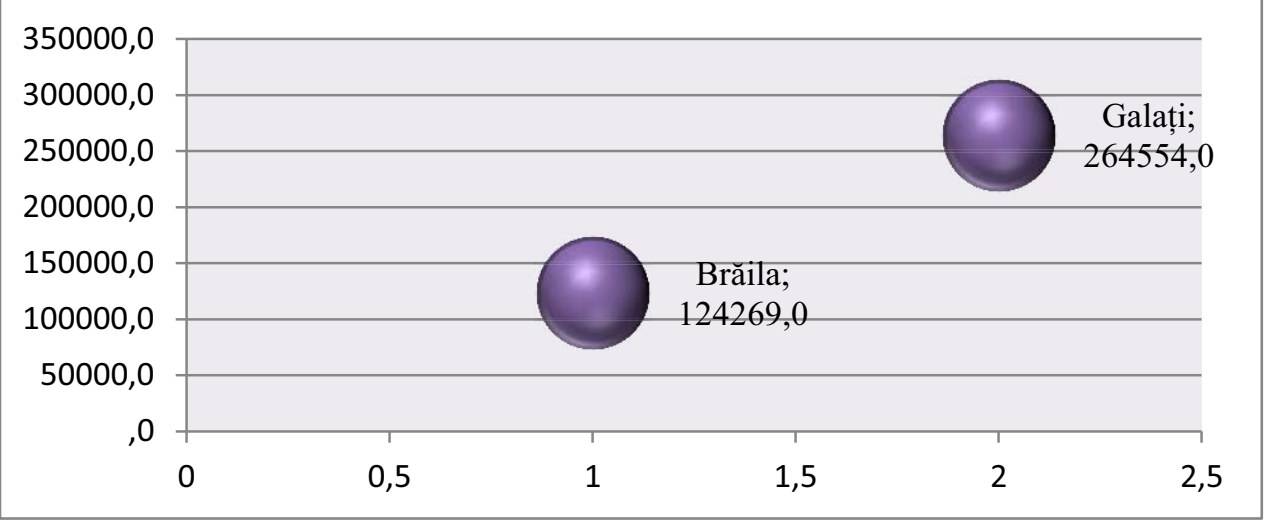

Figure No. 6. The degree of ruralisation in Brăila and Galați

Source: Own processed data from INS

At the level of the region analysed we see that the value of gross domestic product increases very little in 2019 as opposed to 2018. Constanta retains its leadership position in both years analyzed, second place follows Galați and then Brăila.

Figure No. 7. Gross Domestic Product from South-East Region (2019)

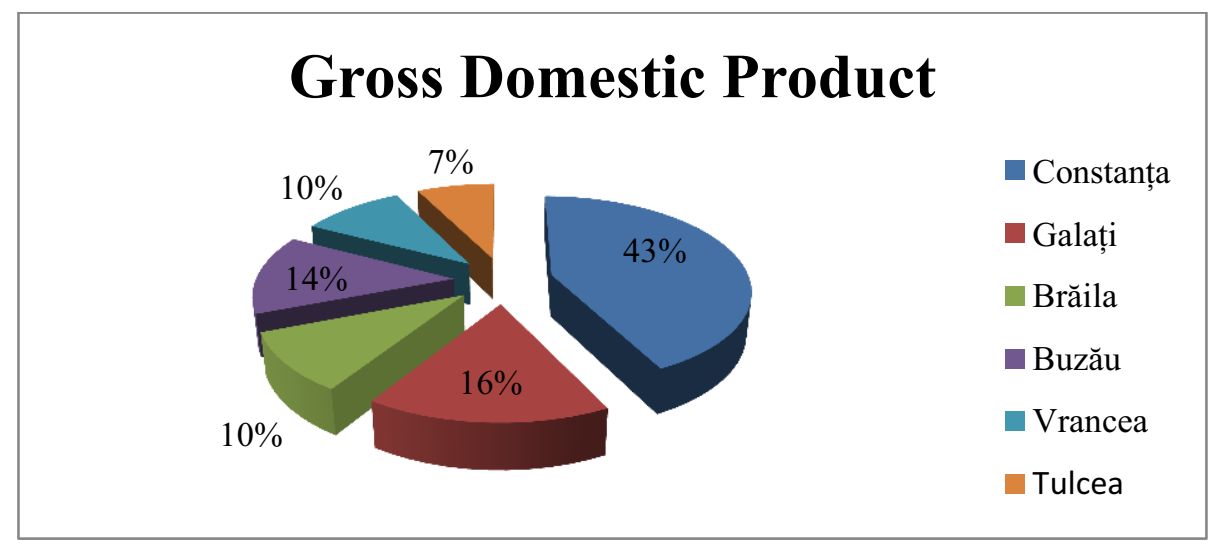

Figure No. 7. Product Inter Gross South-East Region (2019)

Source: Own processed data from the National Strategy and Forecast Commission published in December 2019

Rural areas have a larger gap with urban areas and are defined by: persistent structural deficiencies (increased number of inhabitants in charge of agriculture, ageing population, a large number of subsistence holdings), low value added of agri-food products, lower yields and labour productivity in subsistence agriculture, reduced entrepreneurial spirit in the development of economic activities, reduced access to credit, a non-functioning land market, modest export orientation, investments in relatively insufficient research and development, poorly developed services and infrastructure, large numbers of population at risk of poverty (http://www.madr.ro/docs/dezvoltare-rurala/programare-2014- 
2020/strategia-de-dezvoltare-rurala-2014-2020-versiunea-I-nov2013-update.pdf Accessed 30.03.2020).

The labour market is the space where labour demand meets labour supply and the employed population is the intersection of supply and demand. The supply of labour is characterised by size, population demographic structure, activity rate, number of hours worked per week or per year, quality of labour (skills and skills), attitude towards work and risk, but also location (Kinga K., Bernadett P. Emese S. Eniko V. Development Rural. Employment Labour of Work In Environment Rural, Cluj-napoca, Accent, 2010, Pag 62).

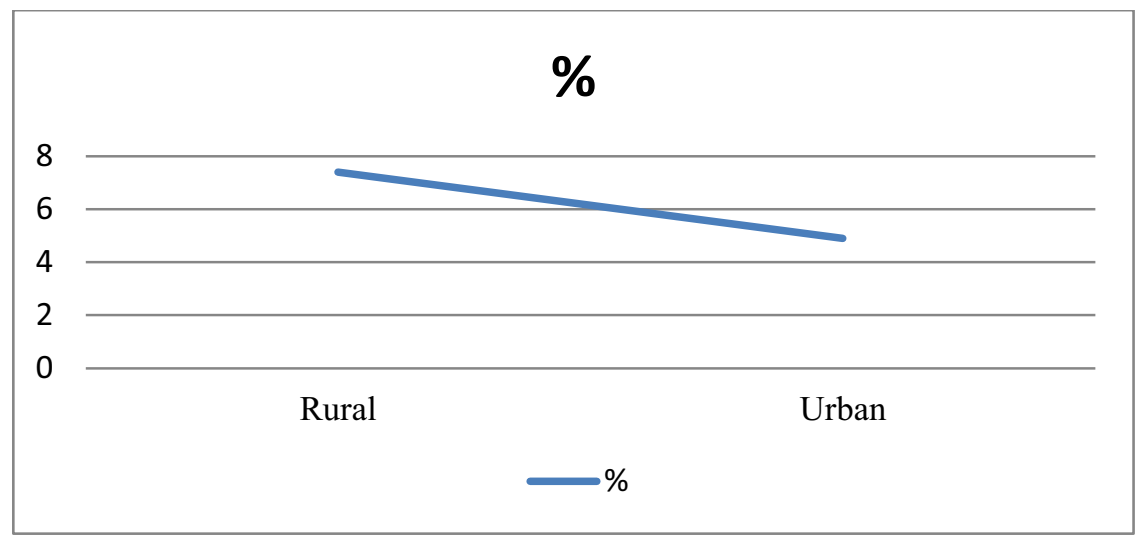

Figure No. 8. South-East Region unemployment rate by residence averages Source: Own processed data from INS, Tempo - Online, November 2020

In recent years, the unemployment rate has been on a downward trend in this region. After careful study of this region we can realize that it is not experiencing a very advanced pace of development. In recent years, the region has seen a reduction in the number of active inhabitants, which is worrying, especially as this reduction is in areas such as agriculture, fisheries, forestry, etc.

\section{Conclusions}

I conclude that the reduction in the number ofinhabitants, as well as the weak economy, have led to a sharp change in the occupational structure majoră galopant of the South-East Region. Labour shortages are common due to migration to European countries.

The South-East region is close to last in terms of the number of employees and the total number of employment contracts concluded. The main industries on which this region is based are services such as tourism or trade, agriculture through the cultivation of cereals or legumes, garments and the shipbuilding industry.

There are large differences between counties such as Galaţi, Constanta or Tulcea, where we experience a higher living crescut compared to counties such as Brăila, Vrancea or Buzău, where the standard of living is lower redus. Constanta is the only county in this region where the number of employment contracts exceeds the national average.

Demographic analysis in the South-East Region shows a decline of the inhabitants here, especially among the youngpopulation. Because the standard of living is much 
lower in this region than in the rest of the country, school dropout and the rather low level of education of the inhabitants, is strongly visible.

In order to improve rural living standards, spațiul bills such as the achievement and provisionof jobs leading to the development of businesses that produce additional income are required.

Attracting young people to the rural area, who are qualified, is an effective method in the plan to reconsolidate the rural area e. Because agricultural activity is the most important pawn in the rural economy, it is necessary to strengthen a system that focuses on its long-term recovery. This can be achieved by expanding a knowledge foundation. It is necessary to modernise and develop agricultural affairs, to synchronise to climate change, but also to use new cutting-edge technologies and European market models.

Support for the modernisation and reorganisationare a of agricultural holdings, the production of quality, the innovation of the processing sector, the potential for the development of processing and marketing, lead to the achievement of new jobs and their preservation.

\section{References}

1. Bold I., Buciuman E., Drăghici N., "Rural area - definition, organization, development ",Timişara, Mirton Publishing House, 2003

2. Botti S., McGill A. L., The Locus of Choice: Personal Cousinity and Satisfaction and Utilitarian Decisions, Journal of ConsumerResearch, 2011

3. Boussand J. M., Introduction toRural Economy, GILLAS Paris Publishing House, 1992.

4. Buhociu F.M., Territorial Resources to Support Sustainable Rural Development in the European Context, Europlus Publishing House, Galați, 2016

5. Kinga K., Bernadett P., Emese S., Eniko V., Rural Development. Rural employment ,ClujNapoca, Accent, 2010

6. Lupaşc I., Lupaşc A., Andone I., Using Intelligent Technologies For Improving Decision Processes,Iasi, 2010

7. Rey V., Atlas of Romania, Ed. RAO, Bucharest, 2006

8. Turek M., Zugravu A., Nicolae C., Rădulescu C., Management of fish farms - effects and opportunities in the functioning of the food market, TerraNostra Publishing House, Iasi, 2011

9. Balasan L. D., Buhociu F.M., Rural development in a cross-border context. Case study: Romania - R. Moldova, at REC June 2019

10. Balasan D. L., Buhociu F. M., 2020, Tourism Evolution in Region 2 SE, Annals of "Lower Danube" University of Galați, Fascicle I. Economics and Applied Informatics

11. Balasan D.L., Buhociu F.M., Ferț C., Structure and Dynamics of Human Resources in the 2SE Region,"Ovidius" University Annals, Economic Science Series, Volume XX, Issue $1 / 2020$

12. Buhociu F.M., Moga L.M., Vîrlănuță F.O., The Quality of Health Services - new instruments for the evaluation, Quality Magazine - access tosuccess, year 10, no. 1-2,2009

13. Buhociu F.M., Antohi V.M., Moga L.M., The Common Agricultural Market and its Effects Upon European Union Countries Agriculture and Budget,Annals of Lower Danube University, Fascicle I, Economics and Applied Informatics, No. 2, 2009

14. Rapid assessment of agriculture and rural development, January 2014 
15. Moga L. M., Buhociu F. M., Ion I., Vîrlănuță F. O., Antohi V., Zugravu A., The Internet as a Business Environment in Romanian Agriculture, Journal ofFood, Agriculture \& Environment ( JFAE) Vol. 7 (2), 2009

16. Onea F., Rusu E., An assessment of the wind and wave power potential in the island environment, Volume 175, 15 May 2019

17. Stanciu S., Security, Safety and Continuity on Agri Food Chain, Lambert Academic PublishingOmniScriptum Publishing Group, 2015

18. Stanciu S., The Foreign Direct Investment in The Romanian Agrifood Production, SEAPractical Application of Science, 2016

19. Stanciu S., A comparative Study Regarding the European Agricultural ALLOCATION OF Funds for Rural Development 2007-2013 and 2014-2020, Advances in Scence, Innovation and Management - Sea 11 International Conference, (April 27-28, 2017, Iasi, Romania), Plenary Conference

20. http://www.madr.ro/docs/dezvoltare-rurala/programare-2014-2020/strategia-de-dezvoltarerurala-2014-2020-versiunea-I-nov2013-update.pdf 